\title{
Helicobacter pylori infection in patients undergoing upper endoscopy at University Hospital in Uheraba, Minas Gerais, Brazil.
}

\author{
| Infe६ผ̧̃o por Helieobacter pyloriem pacientes submetidos à endoseopia digestiva alta em um hospital \\ universitário de Uberaba, Minas Gerais, Brasil.
}

\author{
Fernanda Machado Fonseca ${ }^{1}$ \\ Renata Marnarida Etehebehere ${ }^{1}$ \\ Adriana Gonçalves Oliveira ${ }^{1}$
}

\begin{abstract}
Helicobacter pylori is a Gram negative bacterium that cause chronic gastritis, duodenal ulcers and can predispose the gastric cancer. The study aimed to determinate the prevalence of $\mathrm{H}$. pylori infection by different methods of diagnosis in patients submitted to endoscopy. Of the 145 patients included in the study, were collected fragments of gastric mucosa for histological analysis, and for the rapid urease test. The breath test was also performed. The $\mathrm{H}$. pylori infection was detected in $84(57.9 \%)$ patients by histological study, the rapid test of urease was positive in 81 $(55,8 \%)$ and the breath test in $62(56,3 \%)$. There was no statistically significant difference when comparing the prevalence of infection by different methods of diagnosis. The prevalence of $\mathrm{H}$. pylori infection in our community was lower than that found in the literature for patients with age similar to this study (mean $=53.19$ years).
\end{abstract}

Keywords: Helieobacter pylori prevalence, breath test, preformed urease test, methods of diagnosis.

Deseritores: Heliedbacter pylori, teste respiratório, urease pré-formada, métodos de diagnóstieo.

\section{Resumo}

Helicobacter pylori é uma bactéria gram negativa que causa gastrite crônica, úlceras duodenais e pode predispor ao câncer gástrico. O objetivo deste estudo foi determinar a prevalência da infecção por $\mathrm{H}$. pylori por diferentes métodos de diagnóstico em pacientes submetidos à endoscopia. Dos 145 pacientes incluídos no estudo, foram coletados fragmentos da mucosa gástrica para estudo histopatológico e para a realização do teste da urease pré formada. $O$ teste respiratório também foi realizado. A infecção pelo H. pylori foi detectada em $84(57,9 \%)$ dos pacientes pela análise histológica, o teste rápido da urease foi positivo em 81 (55,8\%) e o teste respiratório em $62(56,3 \%)$. Não houve diferença estatística significante quando comparamos a prevalência da infecção pelos diferentes métodos de diagnóstico. A prevalência encontrada da infecção pelo H. pylori em nossa comunidade foi menor do que a encontrada na literatura em pacientes com a mesma faixa etária (média $=53,19$ anos).

Para correspondência:

Fernanda Machado Fonseca

email: machadofmf@hotmail.com 


\section{Introduction}

Helicobacter pylori is considered as the main cause of chronic gastritis throughout the world. A small percentage of $H$. pylori infected individuals will develop severe diseases such as peptic ulcer, gastric carcinoma, or mucosa-associated lymphoid tissue (MALT) lymphoma ${ }^{1,2}$. In Brazil, some studies have demonstrated differences in prevalence of $H$. pylori infection according to the population evaluated ${ }^{2,3}$.

The aim of this study was to determine the prevalence of $H$. pylori infection using different methods of diagnosis in patients undergoing upper endoscopy at university hospital of the Universidade Federal do Triângulo Mineiro, in Uberaba, Minas Gerais, Brazil.

\section{Methods}

The study was approved by the Ethics Committee of the Universidade Federal do Triângulo Mineiro (UFTM), Uberaba, Minas Gerais (MG), Brazil and was carried out in accordance with the Declaration of Helsinki. All patients signed the informed consent term and answered a questionnaire to obtain socio-demographic data. The clinical information was obtained by reviewing medical records of the patients.

From July 2007 to May 2011, gastric biopsy specimens were obtained from 145 subjects who underwent upper gastrointestinal endoscopy at Endoscopic Service of Universidade Federal do Triângulo Mineiro (UFTM) for evaluation of dyspeptic symptoms. Biopsy specimens were collected from the body and antrum for histopathological study. The gastric fragments were stained by Wartin Starry method for Helicobacter detection ${ }^{4}$. Another fragment of the antral mucosa was obtained for preformed urease test. The ${ }^{13} \mathrm{C}$-urea breath test was performed with a non-dispersive infrared spectrometer (NDIRIS, Wagner Analysen
Technik, Bremen, Germany). A change of $>4.0 \mathrm{~d}$ in ${ }^{13} \mathrm{C}$-value over baseline was considered as $H$. pylori-positive ${ }^{5}$. The exclusion criteria considered were pregnancy, presence of coagulation disorders, complications such as perforation or gastric bleeding, anatomical impediment to endoscopy, esophageal varices, and concomitant severe illness.

\section{Results}

The age of patients ranged of 21 to 84 years, average of 53.19 and standard deviation (SD) of \pm 15.4 years. Ninety-three $(64.1 \%)$ patients were females and $52(35.9 \%)$ males. According to histological analysis, $H$. pylori infection was detected in $84(57.9 \%)$ patients. The rapid test of urease was positive for $81(55,8 \%)$ patients. The ${ }^{13} \mathrm{C}$-urea breath test was performed in 110 of 145 patients and the results was positive for $62(56,3 \%)$ (Table I). There was no statistically significant difference when comparing the prevalence of infection by the different methods of diagnosis used in the present study. All patients $H$. pylori positive for histology were also positive for urease or breath test.

\section{Diseussion and Conelusions}

Epidemiological studies in the state of Minas Gerais found a prevalence of $H$. pylori infection in $82 \%$ of adult patients from the rural area, $69,7 \%$ in adults and children in rural areas of the state and $67 \%$ to $69 \%$ of adults in urban areas $1,2,3,5$. We expected a higher prevalence of $H$ pylori infection than that observed in the present study $(57.9 \%)$ especially if considering that the population evaluated was composed of patients with a level of socio-economic predominantly lower, older and generally came from rural areas. However, despite the low socio economic level, the patients reported having access to basic conditions of hygiene. Additionally, the frequent use of

\begin{tabular}{lccc}
\hline Patients & Histology & Urease test & ${ }^{13}$ C-urea breath test \\
\hline H. pylori positive & $84(57,9 \%)$ & $81(55,8 \%)$ & $62(56,3 \%)$ \\
H. pylori negative & $61(42,1 \%)$ & $64(44,2 \%)$ & $48(43,7 \%)$ \\
Total & $145(100 \%)$ & $145(100 \%)$ & $110(100 \%)$ \\
\hline
\end{tabular}

Table I. Detection of Helicobacter pylori infection by different diagnosis methods in patients submitted to upper endoscopy at hospital of UFTM, Uberaba, Minas Gerais 
proton pump inhibithor by the majority of patients could be favored the elimination of the microorganism ${ }^{6}$. The use of these drugs can favor the $H$. pylori elimination or decrease of amount of bacterium in stomach, especially in the antrum hindering the histopathologic detection of bacterium in gastric biopsies? ${ }^{7}$. Probably, other factor that could be contributed to our result is the frequent monitoring of patients included by medical staff and access to basic conditions of health and hygiene in our community. In conclusion, the prevalence of $H$. pylori infection was lower than that found in the Minas Gerais state for patients with age and level of socioeconomic similar.

\section{Acknowledgements}

We are grateful to medical staff of the Service of Endoscopy at UFTM by their support and by biopsies gastric specimens collected for this study.

\section{Referenees}

1. C LGV, Das SS, Karim QN. Campylobacter pyloridis in the upper gastrointestinal tract: a Brazilian study. Arq Gastroenterol 1987; 24:5-9.

2. Oliveira AMR, Rocha GA, Queiroz DMM, Barbosa MT,
Silva SC. Prevalence of Helicobacter pylori infection in a population from the rural area of the state of Minas Gerais Brazil. Rev Microbiol 1999; 30: 59-61.

3. Fonseca FM, Queiroz DMM, Rocha AMC, Prata A, Crema E, Rodrigues-Junior V, Ramirez LE, Oliveira AG. Seroprevalence of Helicobacter pylori infection in chagasic and non-chagasic patients from the same geographical region of Brazil. Rev. Soc. Bras. Med. Trop 2012; 45: 194-8.

4. Dixon MF, Genta RM, Yardley JH, Correa P, 1996 Classification and grading of gastritis. The updated Sydney System. International Workshop on the Histopathology of Gastritis, Houston. Am J Surg Pathol 1994; 20: 1161-81.

5. Rocha GA, Rocha AMC, Silva LD, Santos A, Bocewicz ACD, Queiroz RM, Bethony J, Gazzinelli A, Corrêa-Oliveira R, Queiroz DMM. Transmission of Helicobacter pylori infection in families of preschoolaged children from Minas Gerais, Brazil. Trop Med Internat Health 2003; 8: 987-91.

6. Lind $T$, Megraud $F$, Unge $P$, Bayerdorffer $E$, O'Morain C, Spiller R, Van ZSV, Bardhan KD, Hellblom M, Wrangstadh M, Zeijlon L, Cederberg C. The MACH2 Study: Role of omeprazole in eradication of Helicobacter pylori with 1-week triple therapies. Gastroenterol 1999; 116: 248-53.

7. Genta RM, Lash RH, Helicobacter pylori-negative gastritis: seek, yet ye shall not always find. Am J Surg Pathol 2010; 34: e25-34 